\title{
$\mathrm{PC/SAN}$ 블렌드의 계면장력에 미치는 저분자량 성분의 영향
}

\author{
양동진 · 손영곤 ${ }^{\dagger}$ \\ 공주대학교 신소재공학부 \\ (2014년 7월 22일 접수, 2014년 9월 2일 수정, 2014년 10월 1일 채택)
}

\section{Effect of Low Molecular Weight Species on the Interfacial Tension of PC/SAN Blend}

\author{
Dongjin Yang and Younggon Son \\ Division of Advanced Materials Science and Engineering, College of Engineering, \\ Kongju National University, Cheonan, Chungnam 331-717, Korea \\ (Received July 22, 2014; Revised September 2, 2014; Accepted October 1, 2014)
}

\begin{abstract}
초록: $\mathrm{PC}$ 와 SAN 사이의 계면장력 및 친화도에 미치는 저분자량 성분의 영향을 알아보기 위하여 용매 추출법으로 각 고분자에서 저분자량 성분을 추출하였다. GPC(gel permeation chromatography)로 분자량 분포를 확인한 결과, 각 고분자의 저분자량 성분은 용매 추출법에 의해 효과적으로 제거된 것을 확인하였다. 저분자량 성분이 제거된 고 분자를 이용하여 계면장력 및 형태학 분석 결과, 저분자량 성분이 제거된 $\mathrm{PC}$ 와 $\mathrm{SAN}$ 은 계면장력이 높아졌고 친화 도가 떨어진 것을 확인할 수 있었다. 즉 저분자량 성분이 두 고분자 사이에 상용화제와 같은 역할을 하는 것을 알 수 있었다. 두 고분자 중 $\mathrm{SAN}$ 의 저분자량 성분이 $\mathrm{PC}$ 의 저분자량 성분보다 상용화 효과에 더 많이 기여하는 것을 확인하였고, 이로서 $\mathrm{PC} / \mathrm{ABS}$ 제조 시 저분자량 성분이 많이 포함된 $\mathrm{SAN}$ 을 사용하는 것이 더 유리하다는 것을 알 수 있었다.
\end{abstract}

\begin{abstract}
Low molecular weight species were extracted from PC and SAN by a solvent extraction method in order to investigate the effect of low molecular weight species on interfacial tension and affinity between PC and SAN. From the analysis of molecular weight distribution by the GPC, it was confirmed that the low molecular weight species were effectively eliminated by the solvent extraction. Interfacial tension measurements and morphological observation were carried out with the PC and SAN of which the low molecular weight species were extracted. Interfacial tension was increased and the infinity was decreased for the extracted PC and SAN pair. This result implied that the low molecular weight species play a role as a compatibilizer between two polymers. Among two polymers, low molecular weight SAN contributes more in the compatibilization. Thus, it is favorable to use SAN containing a larger amount of low molecular weight species in fabrication of PC/ABS blend.
\end{abstract}

Keywords: interfacial tension, low molecular weight, PC, SAN.

\section{서 론}

PC/ABS(polycarbonate/acrylonitrile-butadienestyrene) 블렌 드는 높은 내충격성, 내열성 및 우수한 가공성 때문에 자동 차 부품 및 첨단 정보통신 부품 분야를 포함한 다양한 분야 에 널리 사용되고 있다. $\mathrm{PC} / \mathrm{ABS}$ 는 기본적으로 상 분리된 구 조를 가지는 불균일(immiscible) 고분자 블렌드이지만 다른 고분자 블렌드와는 달리 상용화제(compatibilizer)의 투입 없 이도 우수한 물성의 발현이 가능한 유일한 고분자 블렌드이

${ }^{\dagger}$ To whom correspondence should be addressed.

E-mail: sonyg@kongju.ac.kr

(C)2015 The Polymer Society of Korea. All rights reserved.
다. 이는 $\mathrm{ABS}$ 에 포함된 $\mathrm{SAN}$ (polystyrene-co-acrylonitrile)과 $\mathrm{PC}$ 가 완전한 균일상을 보이지는 않지만 비교적 높은 상용성 을 보이기 때문인 것으로 알려져 있다. ${ }^{1-3}$ 이에 대한 이유로 몇몇 연구자들은 $\mathrm{SAN}$ 에 존재하는 낮은 분자량 성분들이 계 면으로 이동하고 계면을 넘어서 $\mathrm{PC}$ 상으로 이동하여 부분적 인 상용성을 보이기 때문이라고 설명하였다..$^{1-3}$ 즉 일정한 수 준 이상의 분자량을 가지는 $\mathrm{SAN}$ 은 $\mathrm{PC}$ 와 상 분리가 되지만 분자량이 매우 낮은 $\mathrm{SAN}$ 은 $\mathrm{PC}$ 와 균일상(miscible)을 이루고 매우 낮은 분자량의 $\mathrm{SAN}$ 이 $\mathrm{PC}$ 와 높은 분자량 성분의 $\mathrm{SAN}$ 사이에 상용화제 역할을 하여 $\mathrm{PC} / \mathrm{SAN}$ 블렌드의 물성이 상 용화제 없이도 비교적 높은 물성을 보인다는 것이다. ${ }^{4-6}$

Greco와 Iavarone은 $\mathrm{PC} / \mathrm{ABS}$ 에 따로 준비한 매우 낮은 분 
자량의 SAN을 투입하여 투입 양에 따른 기계적 물성 변화, 상 구조 및 상용성 등을 조사하였다. ${ }^{6}$ 그들의 실험 결과에 따 르면 $\mathrm{PC} / \mathrm{ABS}$ 에 소량의 저분자량 $\mathrm{SAN}$ 투입에 따라 $\mathrm{ABS}$ 상 의 $\mathrm{SAN}$ 과 $\mathrm{PC}$ 의 유리전이온도 $\left(T_{\mathrm{g}}\right)$ 가 변하는 전형적인 부분 균일상(partially miscible) 형태를 보였다. 또한 상의 크기는 감소하였고 이에 따라 기계적 물성들도 모두 향상되었다. 따 라서 저분자량 $\mathrm{SAN}$ 이 $\mathrm{PC} / \mathrm{ABS}$ 에서 긍정적인 역할을 하는 것이 확인되었다.

그러나 기존의 연구에서는 저분자량 $\mathrm{SAN}$ 에만 관심이 모 아졌고 저분자량 $\mathrm{PC}$ 의 역할에 관한 연구는 전무한 실정이다. 또한 기계적인 물성, 상 구조 등을 관찰하였으나, 저분자량 $\mathrm{SAN}$ 및 $\mathrm{PC}$ 가 블렌드의 계면장력에 미치는 영향에 관한 연 구는 전무한 실정이다. 계면장력이란 두 상간의 친화도를 나 타내는 척도로 이에 관한 연구가 고분자 블렌드의 연구에 매 우 중요하다고 할 수 있다. 이 연구에서는 SAN과 PC에서 저 분자량 성분을 용액 추출법을 통해 제거하고 제거한 저분자 량 $\mathrm{SAN}$ 과 $\mathrm{PC}$ 가 계면장력에 미치는 영향을 측정하여 $\mathrm{PC} /$ $\mathrm{ABS}$ 블렌드에 미치는 저분자량 성분의 효과에 대하여 연구 하였다. 이 연구에서는 다른 연구에서는 관찰하지 않은 저분 자량 PC 성분의 영향에 관하여 최초로 연구하였다.

\section{실 험}

재료. 실험에 사용된 고분자는 폴리카보네이트(polycarbonate, PC)와 폴리(스티렌-아크릴로니트릴) 랜덤 공중합체 (poly(styrene-r-acrylonitrile), $\mathrm{SAN}$ )이다. $\mathrm{PC}$ 와 $\mathrm{SAN}$ 은 각각 제일모직에서 입수한 그레이드 명 PTULG와 HF5660이었다.

용매 추출법에 의한 저분자량 성분 제거. 두 고분자에 함 유되어 있는 저분자량 성분을 제거하기 위하여 용매 추출법 을 사용하였다. 우선 표면적을 증가시키기 위하여 고분자를 분쇄기에서 고운 입자 형태로 분쇄하고 체로 걸러서 입자 크 기가 약 $50 \mu \mathrm{m}$ 이하인 입자만 사용하였다. 포함된 수분을 제 거하기 위해 12 시간 동안 $60{ }^{\circ} \mathrm{C}$ 에서 진공 건조하였다.

용매(PC: 아세톤, SAN: 메탄올)가 든 Kettle을 heating mantle에 설치하고 교반기를 설치하였다. 온도를 $50{ }^{\circ} \mathrm{C}$ 로 맞 춘 후 용매 양 대비 $10 \mathrm{wt} \%$ 의 고분자를 용매에 투여하고 정 해진 시간 동안 교반하였다. 이때 교반 시간을 시료 명 뒤에 표기하였다. 예를 들어 $\mathrm{SAN} 30$ 이라는 표기는 $\mathrm{SAN}$ 을 메탄올 에서 30 분간 추출한 것을 의미한다. 숫자가 없는 $\mathrm{SAN}$ 이나 $\mathrm{PC}$ 는 용매 추출을 하지 않은 순수한 고분자를 의미한다. 교 반이 종료되면 감압여과장치를 이용해 용매 + 고분자 혼합물 에서 용해되지 않은 대부분의 고분자를 분리하였다. 이 과정 에서 소량의 저분자량 성분이 용매에 녹아 제거되었다. 분리 된 고분자를 다시 한 번 같은 용매를 이용해 1 분간 교반 세 척하였다. 다시 여과한 후 고분자 표면에 남은 잔여 용매를 제거하기 위해 $\mathrm{PC}$ 는 $100{ }^{\circ} \mathrm{C}, \mathrm{SAN}$ 은 $60{ }^{\circ} \mathrm{C}$ 오븐에서 24 시간
동안 건조하였다.

저분자량 성분의 양을 측정하기 위하여 soxhlet 실험을 수 행하였다. 용매 접촉 추출을 완료하고 건조를 통해 용매를 완 전히 제거한 PC 시료를 분쇄하여 $50 \mathrm{mesh}$ 체를 통과시킨 후 원통형 여과지에 $15 \mathrm{~g}$ 을 넣어 준비하였다. Soxhlet 추출기를 이용하여 둥근 플라스크에 아세톤 $300 \mathrm{~mL}$ 를 넣고 플라스크 상부에 원통형 여과지를 넣은 후 추출관과 환류 냉각기를 설 치하고 물 중탕으로 8 시간 동안 추출하였다. $3-4$ 분에 1 회 환 류하도록 온도를 $75{ }^{\circ} \mathrm{C}$ 로 설정하였고 추출이 끝난 후 $140{ }^{\circ} \mathrm{C}$, 진공에서 17 시간 진공 건조를 한 후 감소된 질량을 중량 퍼 센트로 계산하여 저분자량 성분의 함량으로 나타내었다.

계면장력 측정. $\mathrm{PC}$ 와 $\mathrm{SAN}$ 의 계면장력을 retraction of ellipsoidal drop from the imbedded short fiber(이하 RDIF) ${ }^{7}$ 방법으로 측정하였다. 연속상인 $\mathrm{SAN}$ 은 두께 $1 \mathrm{~mm}$, 직경 $25 \mathrm{~mm}$ 인 원판으로 $180{ }^{\circ} \mathrm{C}$ 에서 압축 성형하였다. $\mathrm{PC}$ 는 $250^{\circ} \mathrm{C}$ 로 용융시킨 상태에서 핀셋으로 잡아당겨 섬유 형태로 제조 하였다. 실험에 쓰인 섬유의 직경은 $100 ~ 150 \mu \mathrm{m}$ 정도였다. 제조된 섬유를 길이 $3 \mathrm{~cm}$ 정도로 잘라 바이알에 넣어 $140{ }^{\circ} \mathrm{C}$ 의 진공에서 하루 정도 보관하였는데, 이는 연신 시 생긴 잔 류응력을 제거하기 위함이다. 실험을 시작하기 직전에 장섬 유를 가위로 길이 0.5 에서 $1 \mathrm{~mm}$ 정도의 길이로 잘라 사용하 였다. Hot stage(model Linkam CSS 45)와 비디오 플레이어 에 연결된 광학 현미경으로 투과 모드에서 계면 모양 변화를 기록하였다.

계면장력은 초기 섬유상의 계면이 시간에 따라 구형으로 변해가는 속도를 측정하여 계면장력 값을 계산한다. PC 단섬 유를 $\mathrm{SAN}$ 원판 사이에 놓고 hot stage의 온도를 $150{ }^{\circ} \mathrm{C}$ 로 올 려서 10 분정도 기다린 후 섬유가 원판에 완전히 파묻히도록 hot stage의 위쪽 유리를 살짝 눌러주었다. 이때 $\mathrm{PC}$ 의 유리전 이 온도가 $160{ }^{\circ} \mathrm{C}$ 부근이기 때문에 섬유의 변형 없이 섬유를 $\mathrm{SAN}$ 에 파묻히게 할 수 있다. 섬유가 완전히 파묻힌 것을 확 인한 후 온도를 측정 온도인 $250{ }^{\circ} \mathrm{C}$ 로 빠르게 올렸다. 섬유 상인 $\mathrm{PC}$ 가 녹은 후에는 계면의 형상이 변하기 시작하는 데 마지막 단계에서는 축대칭 타원체에서 구형으로 완화되어 감 을 볼 수 있었고(Figure 2 참조), 이 기록 영상으로부터 Luciani가 유도한 식을 이용하여 계면장력을 구할 수 있다. 타원체 형태의 액적에서 장축 $(L)$ 과 단축 $(B)$ 을 측정하고 이로 부터 구한 변형도(drop deformation parameter, $D=(L-B) /$ $(L+B))$ 는 시간에 따라 변하는데 식 (1)로 표현된다. ${ }^{8}$

$$
D=D_{\mathrm{o}} \exp \left\{-\frac{40(p+1)}{(2 p+3)(19 p+16)} \frac{\sigma}{\eta_{\mathrm{m}} R_{\mathrm{o}}} t\right\}
$$

여기서, $\sigma$ 는 계면장력, $\eta_{\mathrm{m}}$ 는 연속상의 점도, $p$ 는 점도비 그리 고 $R_{\mathrm{o}}$ 는 액적의 반경이다.

계면장력 값은 식 (1)에 나타낸 바와 같이 $\ln (D) v s . t$ 플롯 의 기울기로부터 구할 수 있다. 
특성 분석. 용매 추출에 의하여 저분자량 성분이 추출된 SAN 및 PC의 분자량을 GPC(gel permeation chromatography) 를 이용하여 측정하였다. 사용된 GPC는 ViscoTek사의 모델 명 $\mathrm{GPC} 1007$ 이였고 dichloromethane에 $0.002 \mathrm{~g} / \mathrm{mL}$ 의 농도로 유량 $1.0 \mathrm{~mL} / \mathrm{min}$ 으로 측정하였다. 표준 시료는 폴리스티렌을 사용하였다. 계면장력을 계산하려면 영점 전단점도(zero-shear viscosity)가 필요하다. 영점 전단 점도는 advanced rheometric expansion system(ARES)을 이용하여 일정 모드(steady mode) 에서 전단 점도를 측정하여 구하였다. 온도는 계면장력 측정 실험과 같은 $250^{\circ} \mathrm{C}$ 였다.

$\mathrm{SAN} / \mathrm{PC}$ 블렌드의 형태학적 상 구조를 관찰하기 위하여 SAN $10 \mathrm{wt} \%$ 와 PC $90 \mathrm{wt} \%$ 를 정량하여 배치 믹서(Haake PolyLab QC3000)에서 10분간 용융 혼련하였다. 혼련 온도는 $250{ }^{\circ} \mathrm{C}$, 로터 회전 속도는 $50 \mathrm{rpm}$ 이었다. 혼련된 블렌드는 $200{ }^{\circ} \mathrm{C}$ 에서 압축 성형하여 충격 시편을 제조하였다. 충격시 편을 액체 질소에서 파단하고 파단면을 백금 코팅하였다. 코 팅된 면의 미세구조를 주사전자현미경(JEOL JSM-6335F)으 로 관찰하였다. ImageJ(NIH Image, http://rsb.info.nih.gov/ nih-image/)라는 이미지 분석 소프트웨어를 사용하여 얻어진 $\mathrm{SEM}$ 사진에서 PC 상의 크기를 정량적으로 측정하였다. 200 에서 300 개의 상을 측정하여 평균 크기를 정하였다. 수평균 상의 크기 $\left(D_{\mathrm{n}}\right)$ 와 부피평균 상의 크기 $\left(D_{\mathrm{v}}\right)$ 는 다음과 같이 정 의된다.

$$
\begin{aligned}
& D_{\mathrm{n}}=\Sigma n_{\mathrm{i}} D_{\mathrm{i}} / \Sigma n_{\mathrm{i}} \\
& D_{\mathrm{v}}=\Sigma n_{\mathrm{i}} D_{\mathrm{i}}^{3} / \Sigma n_{\mathrm{i}} D_{\mathrm{i}}^{2}
\end{aligned}
$$

\section{결과 및 토론}

Figure 1에 세 종류 $\mathrm{PC}$ 의 분자량 분석 결과를 나타냈다. 용 출 부피(retention volume)가 낮은 경우 즉 분자량이 높은 성 분의 경우 세 $\mathrm{PC}$ 가 거의 일치하는 결과를 보여주었고 용출 부피가 큰 경우(분자량이 낮은 성분)에는 약간의 차이를 보 였다. 용매 추출하지 않은 순수한 PC는 낮은 분자량 성분이 제일 많았고 용매로 추출한 시간이 길어질수록 분자량이 낮 은 성분들이 추출되어 전체 분자량은 약간씩 증가하는 것을 볼 수 있다. 이로서 용매 추출법이 낮은 분자량 성분을 잘 추 출한다는 것을 확인하였다. $\mathrm{SAN}$ 의 경우에도 유사하게 추출 시간이 증가할수록 낮은 분자량 성분이 추출되어 점도가 증 가한 것을 확인할 수 있었고 이로부터 평균 분자량이 증가하 는 것을 알 수 있었다. 또한 Soxhlet 실험을 통하여 시료에 포함된 저분자량 성분의 양을 측정한 결과 용매 추출하지 않 은 순수한 $\mathrm{PC}$ 는 $2.6 \%, \mathrm{PC} 30$ 및 $\mathrm{PC} 60$ 은 각각 $1.3 \%$ 와 $0.95 \%$ 의 저분자량 성분을 함유하는 것을 확인하였는데 이로서 용 매 추출에 의하여 저분자량 성분이 효과적으로 제거되었음을 확인할 수 있었다.

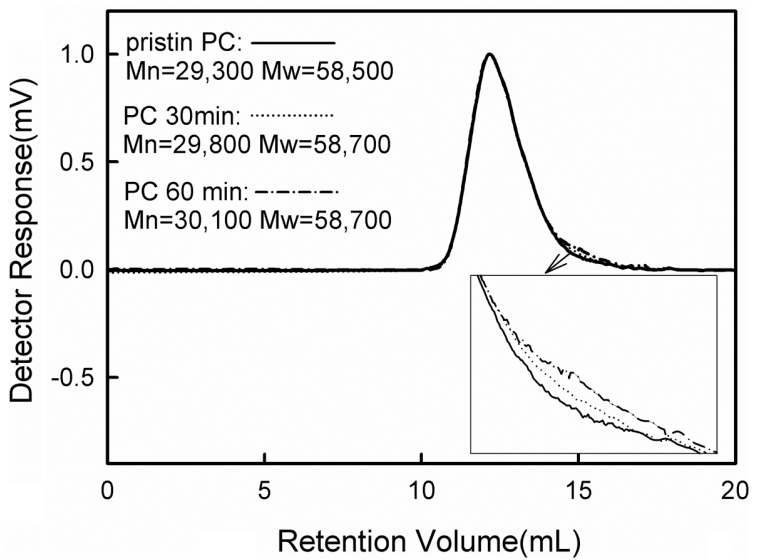

Figure 1. GPC results for pristine PC, PCs extracted for $30 \mathrm{~min}$ and $60 \mathrm{~min}$, respectively.

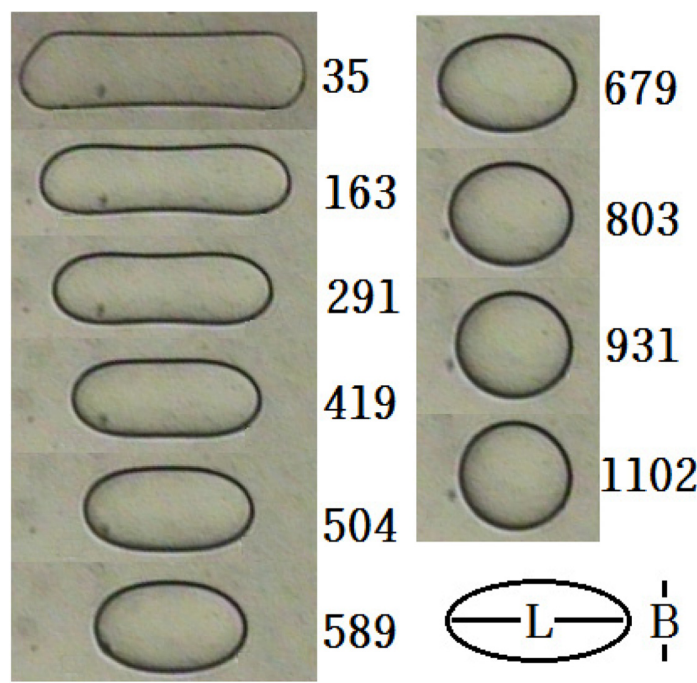

Figure 2. Optical micrograph of the retraction process for the ellipsoidal PC drop suspended in SAN phase. The numbers shown in the micrographs represent elapsed time in seconds.

저분자량 성분을 추출한 $\mathrm{PC}$ 와 $\mathrm{SAN}$ 을 이용하여 계면장력 을 측정하였다. Figure 2에 PC/SAN의 계면장력 측정 시 PC 액적(drop)이 시간에 따라 변해가는 모양을 나타냈다. 이 모 양을 분석해 계면장력을 측정할 수 있다. 초기에 짧은 섬유 형태의 PC 상이 시간이 지남에 따라 점점 타원체의 형태로 바뀌어 간 후 최종적으로 원형의 액적으로 변한다. 이때 RDIF 법에 의하여 계면장력을 측정하기 위해서는 액적의 형태가 완벽한 축대칭 타원체(axisymmerical ellipe)이어야 한다. ${ }^{7.8}$

Figure 2에 나타낸 액적의 형태가 완벽한 축대칭 타원체인 지를 확인하기 위하여 504초와 589초의 액적 윤곽과 이에 가 장 근접한 타원곡선을 Figure 3에 나타냈다. 504초에서 액적 의 윤곽은 타원형에서 다소 벗어나지만 589 초에서는 거의 타 원형임을 볼 수 있고 그림에는 나타내지 않았지만 그 이후의 


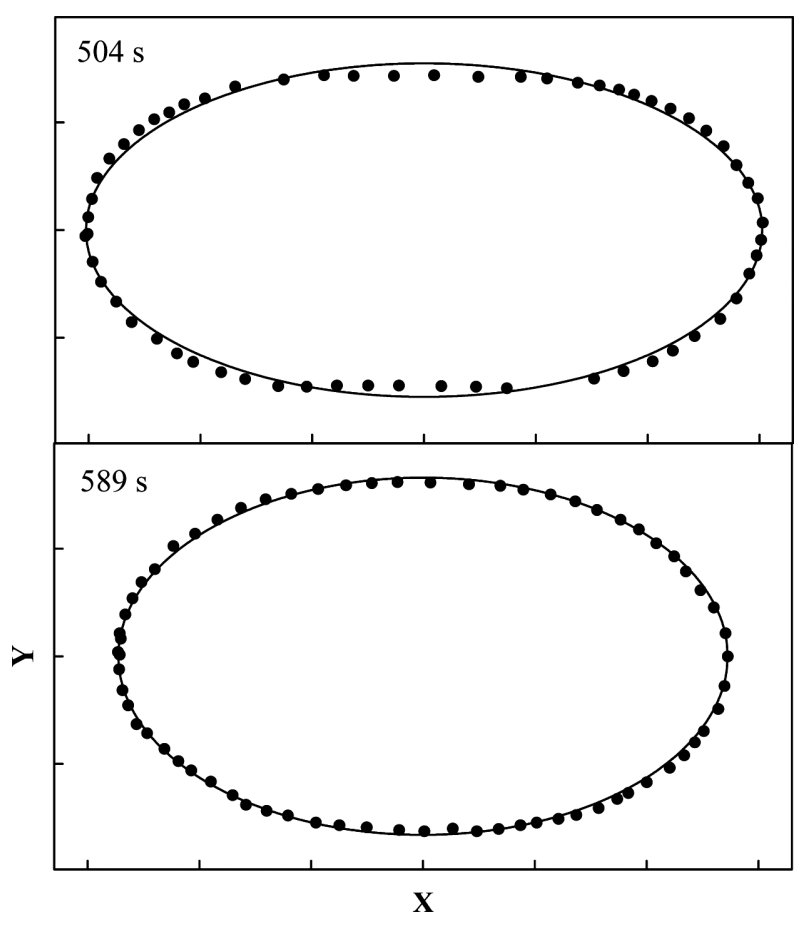

Figure 3. Comparison of experimental contours and equivalent ellipses at 504 and $589 \mathrm{~s}$ for the data shown in Figure 2.

액적 들은 모두 완벽한 타원형임을 확인하였다. 따라서 Figure 2 에 나타낸 사진 데이터에서 589 초 이후의 데이터를 이용하 여 계면장력을 구할 수 있다. 그러나 모든 사진 데이터의 윤 곽을 타원 곡선과 비교하기는 많은 시간과 수고가 필요하다.

Figure 4에 액적의 변형도 $(D=(L-B) /(L+B))$ 와 무차원 부피 (dimensionless volume)를 시간의 함수로 나타냈다. 여기서 무 차원 부피는 겉보기 부피(apparent volume, Figure 2의 사진 데이터에서 얻은 장축과 단축 $L, B$ 로부터 구한 타원체의 부 피 $\left.\pi L B^{2} / 6\right)$ 를 최종 구형 액적의 부피 $3 \pi R^{3} / 4$ 로 나눈 값이다. 사진에서 구한 액적의 윤곽이 완전한 타원체이고 타원체가 축 대칭이라면 이렇게 구한 부피는 실제 액적의 부피와 같을 것이고 무차원 부피는 1 로 계산이 될 것이다. Figure 4 의 시 간에 따른 무차원 부피를 보면 초기에는 1 보다 적은 값을 보 이다가 완화의 마지막 단계에서는 1 에 수렴함을 볼 수 있다. 초기에는 액적의 형태가 타원형에서 벗어나서 1 이 아닌 값을 보이지만 액적의 형태가 타원체가 되는 589초 이후에는 무 차원 부피가 1 에 수렴하는 값을 보이고 $\ln (D) v s . t$ 플롯의 기 울기도 일정한 값에 수렴함을 볼 수 있다. 액적의 윤곽 분석 결과(Figure 3)와 시간에 따른 변형도 및 무차원 부피 분석 결과(Figure 4)를 종합해 본 결과 무차원 부피가 0.95보타 큰 경우 액적이 축대칭 타원형을 보이는 것으로 판단하였다. 따 라서 이 연구에서는 무차원 부피가 0.95 보다 큰 데이터로부 터 계면장력을 구하였다.

구한 계면장력 값을 Table 1과 Figure 5에 나타냈다. 계면

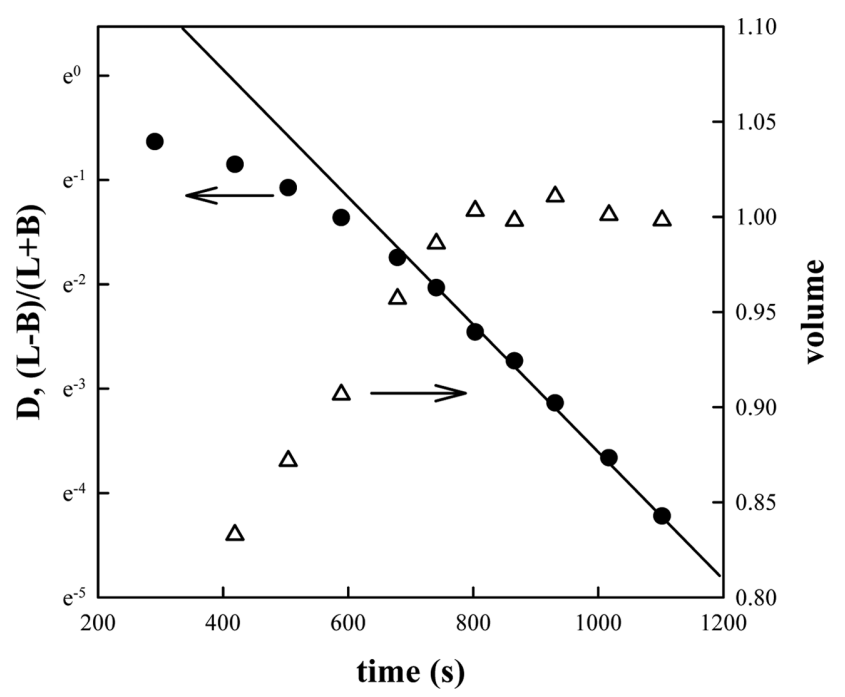

Figure 4. Typical example for time evolution of deformability and the dimensionless apparent volume for PC/SAN pair.

장력 값은 저분자량 성분을 추출하지 않은 $\mathrm{PC} / \mathrm{SAN}$ 의 경우 가 $1.67 \mathrm{mN} / \mathrm{m}$ 로 제일 낮은 값을 보였고, 저분자량 성분이 줄 어들수록 증가하였다. 예를 들어 $\mathrm{PC} / \mathrm{SAN} 30$ 의 경우는 PC/ $\mathrm{SAN}$ 에 비해 $35 \%$ 정도 계면장력 값이 증가했고 $\mathrm{PC} / \mathrm{SAN} 60$ 은 $47 \%$ 정도의 계면장력 증가를 보였다. 이는 전술한 바와 같이 SAN에 존재하는 저분자량 성분이 $\mathrm{PC}$ 상으로 이동하여 상용성을 높여주기 때문으로 해석된다. 저분자량 성분을 추

Table 1. Interfacial Tension Values $(\mathrm{mN} / \mathrm{m})$ between $P C$ and SAN Pair

\begin{tabular}{cccc}
\hline Polymer & SAN & SAN30 & SAN60 \\
\hline PC & 1.67 & 2.25 & 2.45 \\
PC30 & 1.92 & 2.37 & 2.49 \\
PC60 & 2.13 & 2.35 & 2.57 \\
\hline
\end{tabular}

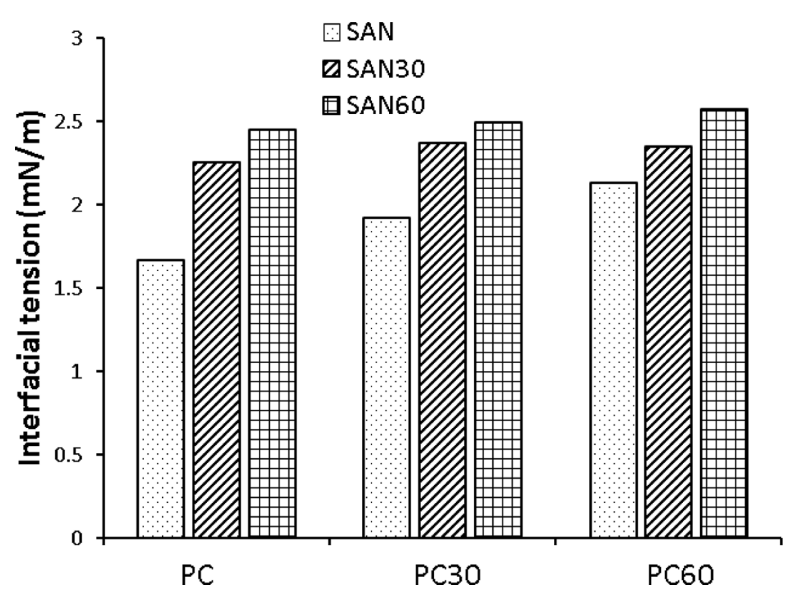

Figure 5. Graphical presentation of interfacial tension values between PC and SAN pair. 
출하지 않은 순수한 $\mathrm{SAN}$ 에는 저분자량 성분이 다량 포함되 어서 $\mathrm{PC}$ 와 상용성을 높여주고 결국 낮은 계면장력 값을 보 인다고 생각된다. 반면, 용매 추출을 거친 SAN30, SAN60 들 은 저분자량 성분이 상당 부분 추출되었고 이로 인해 더 높 은 계면장력 값을 나타낸다고 해석된다.

이 연구에서는 최초로 $\mathrm{PC}$ 에서 저분자량 성분을 추출해 내 고 그 영향을 살펴보았다. 저분자량 $\mathrm{SAN}$ 과 마찬가지로 저분 자량 $\mathrm{PC}$ 도 $\mathrm{PC}$ 와 $\mathrm{SAN}$ 사이에서 상용화제의 역할을 할 가능 성이 있다고 판단되어 이 실험을 수행하였다. $\mathrm{SAN}$ 과 $\mathrm{PC}$, $\mathrm{PC} 30$ 및 $\mathrm{PC} 60$ 과의 계면장력 값을 보면 $\mathrm{PC}$ 의 추출 시간이 늘어날수록 그 값이 증가하는 것을 볼 수 있다. 즉 순수한 $\mathrm{SAN}$ 의 경우는 $\mathrm{PC}$ 에서 저분자량 성분이 추출되어 제거될수 록 두 고분자간의 계면장력의 값이 약간 증가하는 경향을 보 인다. 그러나 SAN30 및 SAN60과 같이 저분자량 성분이 추 출된 $\mathrm{SAN}$ 에 대해서는 $\mathrm{PC}$ 에서 저분자량 성분을 추출해도 계 면장력 값에는 큰 영향을 미치지 못하는 것을 볼 수 있다. 또 한 전반적으로 저분자량 $\mathrm{SAN}$ 성분이 저분자량 $\mathrm{PC}$ 성분에 비해서 계면장력이 훨씬 더 큰 영향을 미치는 것을 관찰할 수 있다.

$\mathrm{PC} / \mathrm{SAN}$ 은 부분적인 상용성을 지니는 고분자 블렌드로 알 려져 있다. ${ }^{9,10}$ 예를 들어 Chun 등의 ${ }^{10}$ 실험에 의하면 $\operatorname{PC}\left(T_{\mathrm{g}}\right.$ $\left.=156^{\circ} \mathrm{C}\right)$ 와 $\mathrm{SAN}\left(T_{\mathrm{g}}=107^{\circ} \mathrm{C}\right)$ 를 $9 / 1$ 또는 $1 / 9$ 로 혼합하면 전자 의 경우 114 와 $144{ }^{\circ} \mathrm{C}$, 후자의 경우 107 와 $140{ }^{\circ} \mathrm{C}$ 에서 두 개 의 $T_{\mathrm{g}}$ 가 관찰된다. $\mathrm{Fox}$ 식에 의하여 두 상에서 $\mathrm{PC}$ 와 $\mathrm{SAN}$ 의 조성을 계산해보면 $\mathrm{PC}$ 를 $90 \% \mathrm{SAN}$ 을 $10 \%$ 혼합한 경우는 $\mathrm{PC}: \mathrm{SAN}=0.777: 0.233$ 인 $\mathrm{PC}$ rich phase와 $\mathrm{PC}: \mathrm{SAN}=0.158$ : 0.842 인 $\mathrm{SAN}$ rich phase로 상분리가 이루어지고 $\mathrm{PC}$ 를 $10 \%$ $\mathrm{SAN}$ 을 $90 \%$ 혼합한 경우는 $\mathrm{PC}: \mathrm{SAN}=0: 1$ 인 SAN rich phase 와 $\mathrm{PC}: \mathrm{SAN}=0.30: 0.70$ 인 $\mathrm{PC}$ rich phase로 상분리가 이루어진 다. 이 결과를 보면 $\mathrm{SAN}$ 은 비교적 많은 양이 $\mathrm{PC}$ 상으로 이 동하는데 반해 $\mathrm{PC}$ 는 $\mathrm{SAN}$ 에 비해서 소량이 $\mathrm{SAN}$ 상으로 이 동하는 것을 알 수 있다. 따라서 저분자량 성분이 상용화제 역할을 하기에는 $\mathrm{PC}$ 가 근본적으로 $\mathrm{SAN}$ 에 비해서 불리한 특 성을 가지고 있다고 할 수 있다. 이는 이 연구에서 보여준 실 험 결과와도 일치한다. 따라서 이 연구 결과, 알 수 있는 사 실은 $\mathrm{PC} / \mathrm{ABS}$ 제조 시 두 성분의 상용성을 높이기 위해서 $\mathrm{SAN}$ 은 분자량 분포가 넓은 종(저분자량 성분이 다수 포함된 종류)을 사용하는 편이 유리하고 $\mathrm{PC}$ 의 경우는 강도 및 물성 을 위하여 높은 분자량을 사용하는 것이 유리하다는 것이다.

Figure 6에 PC/SAN, PC30/SAN 및 PC60/SAN의 SEM 사 진을 나타냈다. 또한 이미지 분석을 통하여 측정된 수평균 상 의 크기와 부피 평균 상의 크기도 사진 아래에 나타냈다. 그 림에서 볼 수 있듯이 $\mathrm{PC}$ 에서 저분자량 성분을 제거할수록 $\mathrm{SAN}$ 도메인의 크기가 줄어드는 것을 볼 수 있다. 이것은 전 술한 바와 같이 저분자량 성분이 $\mathrm{SAN}$ 성분으로 이동하여 상 용화제와 같은 역할을 하기 때문이다. 그러나 $\mathrm{SAN}$ 에서 저분

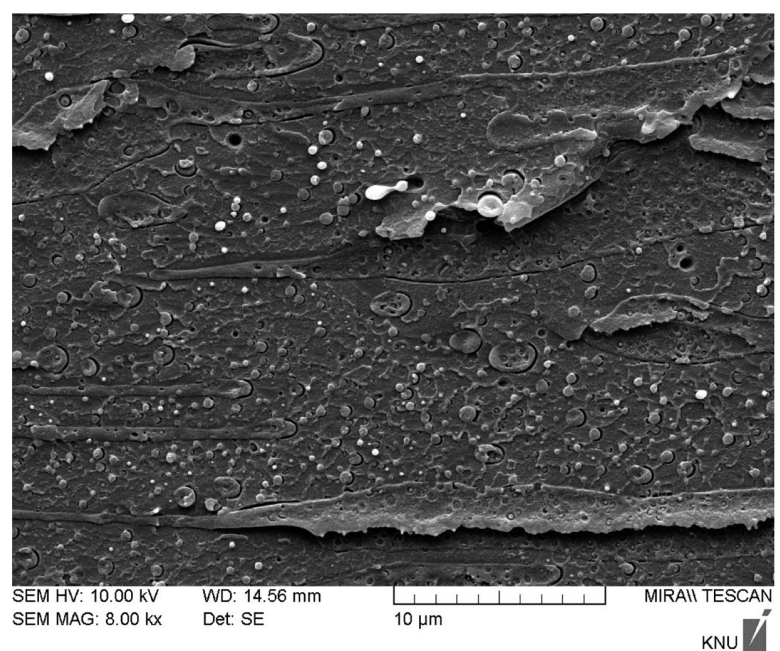

(a) $\mathrm{D}_{\mathrm{n}}=0.66 \mu \mathrm{m}, \mathrm{D}_{\mathrm{v}}=0.83 \mu \mathrm{m}$

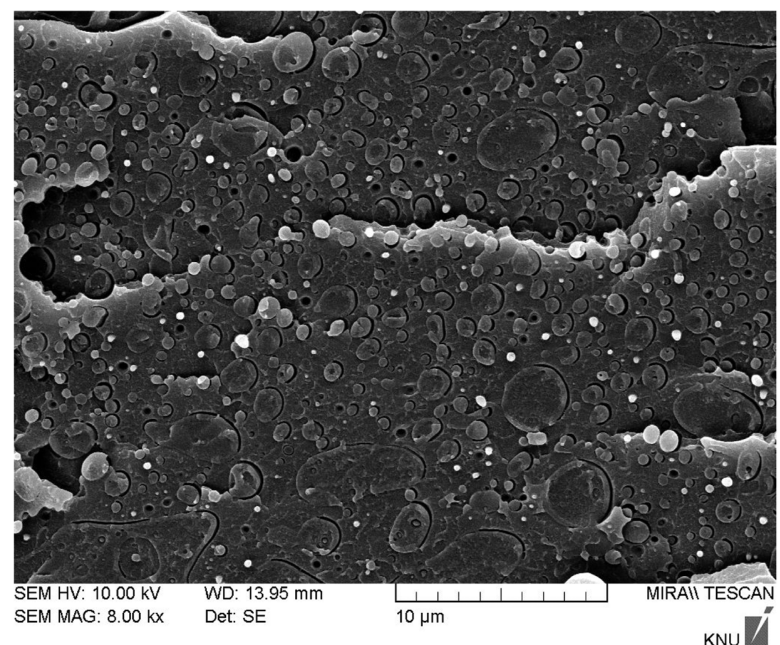

(b) $\mathrm{D}_{\mathrm{n}}=0.83 \mu \mathrm{m}, \mathrm{D}_{\mathrm{v}}=1.27 \mu \mathrm{m}$

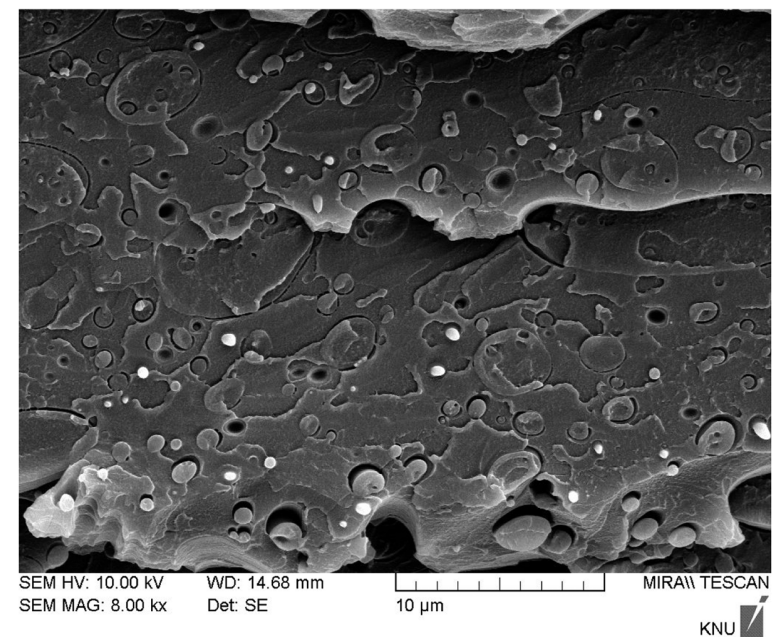

(c) $\mathrm{D}_{\mathrm{n}}=1.22 \mu \mathrm{m}, \mathrm{D}_{\mathrm{v}}=1.99 \mu \mathrm{m}$

Figure 6. SEM micrographs for (a) PC/SAN; (b) PC30/SAN; (c) PC60/SAN blends. 
자량 성분을 제거한 $\mathrm{SAN} 30$ 과 $\mathrm{SAN} 60$ 을 이용하여 동일한 $\mathrm{SEM}$ 관찰을 했을 때에는 $\mathrm{PC}$ 에서 저분자량 성분을 제거한 경우에도 순수한 $\mathrm{PC}$ 와 비교하여 $\mathrm{SAN}$ 도메인의 크기가 약간 줄어드는데 그쳤는데 이는 계면장력 결과와 유사한 경향을 보인다. 비상용 고분자 블렌드에서 도메인의 크기는 두 상간 의 계면장력에 반비례하므로 서로 일치하는 결과라고 할 수 있다. ${ }^{11}$ 따라서 계면장력 실험과 형태학 분석을 통하여 $\mathrm{PC}$ 의 저분자량 성분은 $\mathrm{SAN}$ 저분자량 성분에 비하여 상용화제의 기능이 떨어진다고 할 수 있다.

\section{결 론}

저분자량 성분을 제거한 $\mathrm{PC}$ 와 $\mathrm{SAN}$ 은 제거하지 않은 경우 와 비교해서 높은 계면장력 값을 보였고 친화도가 떨어졌다. 이는 두 고분자의 저분자량 성분이 상용화제와 같은 역할을 한다는 것을 의미한다. 두 고분자에서 한 고분자만 저분자량 성분을 제거하여 실험을 한 결과 $\mathrm{PC}$ 보다는 $\mathrm{SAN}$ 에 있는 저 분자량 성분이 상용화 효과가 더 큰 것을 알 수 있었다. 따 라서 $\mathrm{PC} / \mathrm{ABS}$ 제조 시 두 성분의 상용성을 높이기 위해서 저 분자량 성분이 더 많이 포함된 $\mathrm{SAN}$ 을 사용하는 편이 유리 하고 $\mathrm{PC}$ 의 경우는 강도 및 물성을 위하여 높은 분자량을 사 용하는 것이 유리하다는 것을 알 수 있었다.
감사의 글: 이 논문은 2013년 공주대학교 학술연구지원사 업의 연구비지원에 의하여 연구되었음.

\section{참 고 문 헌}

1. T. A. Callaghan, K. Takakuwa, D. R. Pual, and A. R. Padwa, Polymer, 34, 3796 (1993).

2. J. D. Keith, J. W. Barlow, and D. R. Paul, J. Appl. Polym. Sci., 29, 3131 (1984).

3. V. K. Stokes and S. Y. Hobbs, Polymer, 34, 1222 (1993).

4. R. Greco, "Polycarbonate Toughening by ABS," in Aduanced Routes for Polymer Toughening, E. Martuscelli, P. Musto, and G. Ragosta, Editors, Elsevier, Amsterdam, pp 469-526 (1996).

5. R. Greco, "Natural Polymer Alloys: PC/ABS Systems," in Polymer Alloys and Blends, G. O. Shonaike and G. P. Simon, Editors, Marcel Dekker Publ., Chapter 11, pp 289-330 (1999).

6. R. Greco and M. Iavarone, Polym. Eng. Sci., 40, 1701 (2000).

7. Y. Son and K. D. Migler, Polymer, 43, 3001 (2002).

8. A. Luciani, M. F. Champagne, and L. A. Utracki, J. Polym. Sci. Polym. Phys. Ed., 35, 1393 (1997).

9. R. A. Mendelson, J. Polym. Sci. Polym. Phys. Ed., 23, 1975 (1985).

10. J. Chun and K. Maeng, J. Mat. Sci., 26, 5347 (1991).

11. S. Wu, Polym. Eng. Sci., 27, 335 (1987). 